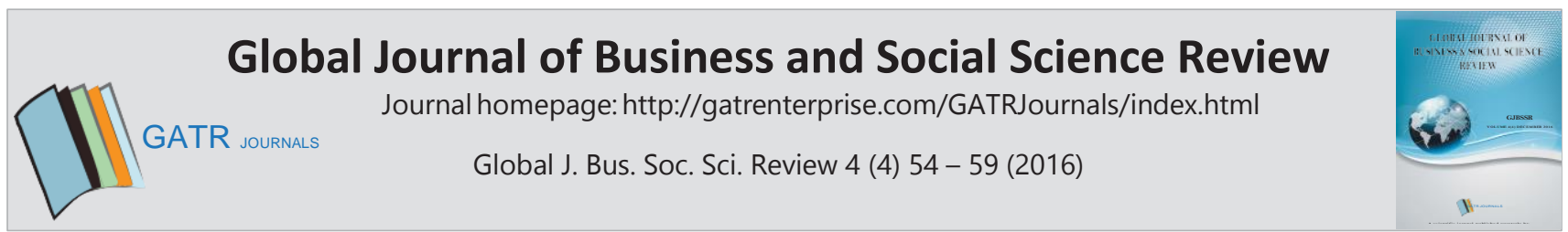

\title{
Success of prediction models in Slovak companies
}

\author{
Ivana Podhorska ${ }^{*}$ and Maria Misankova ${ }^{2}$ \\ 1,2 University of Zilina, Faculty of Operations and Economics of Transport and Communications, Department of Economics, Univerzitná \\ 1, 01026 Žilina, Slovak Republic
}

\begin{abstract}
Objective - The issue of bankrupt of company is very actual topic not only in Slovakia but also in abroad. The reason is that many companies have problem with the question of their probability of default or bankrupt and also with their financial health as a whole. This paper deals with the issue of prediction models and captures the applicability of these models in the Slovak conditions.

Methodology/Technique - In this paper are applied eight selected prediction models in the sample of 74 companies from Slovak Republic. In addition, this paper calculated one financial ratio from the category of company's indebtedness. Based on this calculation is done the comparison between results of predictions models and results of indebtedness financial ratio. Findings - They tested eight different prediction models and their findings present that best results were achieved by Fulmer, Poznanski and Zmijewski model. Weak results achieved IN05, CH-index and Sharita model.

Novelty - This paper provides explanatory ability and success of individual prediction models in Slovak conditions.

Type of Paper: Review
\end{abstract}

Keywords: Prediction Models; Financial Health; Bankrupt; Non-Bankrupt; Indebtedness Financial Ratio. JEL Classification: G33, I19, K35.

\section{Introduction}

Currently the issue of company bankruptcy belongs to the quite often discussed interdisciplinary challenges of modern understanding of the corporate finance. This topic is up to date not only in Slovakia but also in abroad. There are many companies that have problems with their potential bankruptcy and their financial health as a whole. Bankruptcy of company directly affects all subjects entering into a relationship with that company. This is the reason why is important to exploring the possibilities of prediction the financial health of companies it means to search early warning signal for financial problems of company or its bankruptcy itself. Spuchlakova et al. (2015) Financial analysts are looking ways by which we will be able to predict companies default. One of the useful tools for measure probability of default is prediction models from financial analysis ex-ante. Based on the results of the ex-post analysis with using specific methods, these models predict the financial situation of company in the future. Kollar et al. (2015) In this paper we will try to point out the possibilities of using the selected prediction models for monitoring the financial health of Slovak companies. For our calculation we chose 74 companies from Slovak Republic, this was random selection. We chose companies from different regions,

\footnotetext{
Paper Info: Revised: September 10, 2016

Accepted: October 6, 2016

* Corresponding author:

E-mail: ivana.podhorska@fpedas.uniza.sk

Affiliation: PhD. student, University of Zilina, Slovak Republic
} 
with different type of business, number of employees and so on. As representative models for monitoring the financial health of selected companies we chose 8 prediction models. As input data we used information from financial statements of selected companies in 2015.

\section{Theoretical background}

The beginning of this chapter will be devoted to a brief historical development of prediction models. As we mentioned above, the issue of prediction the financial situation of company has attracted professional public attention since 60th of $20^{\text {th }}$ century. As a pioneer in the field of prediction models can be considered Beaver (1966) which identified a simple ratio based on which can be predicted the bankrupt of company. Beaver study was followed up by Altman (1968) who has worked with multidimensional technique also known as multidimensional discriminant analysis. In the 80th of $20^{\text {th }}$ century Logit and Probit models have appeared which are based on the logistic regression. For example, Ohlson (1980) used a Logit model for prediction of company's bankruptcy. Later (2004) Hillegesit (2004) and Shumway (2001) criticized Logit and Probit models for their inexact results, inefficiency and inconsistency of the estimated coefficient. At present, also they use the different types of heuristic algorithms (neural networks or decision trees), which also can be applied to the prediction of bankruptcy. As we mentioned above, prediction models belong to the ex-ante financial analysis. It means that their primary function is to forecasting the financial health of company. Traditionally, we can divide prediction models into the several main categories, namely: bankruptcy models, creditworthy models, Logit and Probit models and structural prediction models. In this paper, we chose 8 prediction models from different categories, based on the different criteria. In the second part of this chapter we will deal with the methodology which we applied in this paper. Our methodology we can divide into the three basic steps that are described below. Fulmer (1984), Sharita (1995)

In the first step we had to choose some suitable companies from Slovak Republic. Our selection was random. We chose companies from different regions, with different number of employees and with different type of business. For the purposes of our article, we had to obtain their financial statements. For our calculations we used their financial statements for 2015. Finally, we chose 74 companies which are placed in Slovak Republic. These 74 companies were our basic sample. In this sample we had two categories of companies. The first one was bankrupt companies and this category contained 8 companies, the second one was non-bankrupt companies and this category contained 66 companies.

In the second step was necessary to choose prediction models that can be calculated in selected companies. In this case we decided for random selection. Especially, we chose 5 prediction models from the category of bankruptcy models which are based on the multidimensional discriminant analysis, namely: Springate model, Poznanski model, Fulmer model, IN05 and CH-index. From the category of Logit and Probit models we chose Zmijewski model, Jakubík-Teplý model and Sharita model, these models are based on the logistics regression. Kliestik, Majerova (2015) For our selection was interesting the environment in which was the model created, $\mathrm{CH}$-index was created in Slovak Republic, IN05 model and Jakubík-Teplý model were created in Czech Republic and we also chose Poznanski model which was created in Poland. Our aim in this second step was to apply and calculate 8 prediction models in our sample of 74 companies from Slovak Republic based on data from their financial statements for 2015. At the end of the second step, which describes the part of the methodology of this paper, we provide the brief descriptions of theoretical aspects of our selected prediction models. Springate (1983), Zmijewski (1984) 
Table 1. Theoretical aspects of selected prediction models

\begin{tabular}{|c|c|c|c|}
\hline Model & Country & Year & Category \\
\hline Springate model & CAN & 1978 & Bankruptcy \\
\hline \multicolumn{4}{|c|}{$\mathrm{S}=1.03 \mathrm{x}_{1}+3.07 \mathrm{x}_{2}+0.66 \mathrm{x}_{3}+0.4 \mathrm{x}_{4}$} \\
\hline Poznanski model & PL & 2002 & Bankruptcy \\
\hline \multicolumn{4}{|c|}{$\mathrm{FD}=3.562 \mathrm{x}_{1}+1.588 \mathrm{x}_{2}+4.288 \mathrm{x}_{3}+6.719 \mathrm{x}_{4}-2.368$} \\
\hline Fulmer model & USA & 1984 & Bankruptcy \\
\hline \multicolumn{4}{|c|}{$\mathrm{F}=5.528 \mathrm{x}_{1}+0.212 \mathrm{x}_{2}+0.073 \mathrm{x}_{3}+1.270 \mathrm{x}_{4}-0.120 \mathrm{x}_{5}+2.335 \mathrm{x}_{6}+0.575 \mathrm{x}_{7}+1.083 \mathrm{x}_{8}+0.894 \mathrm{x}_{9}-6.075$} \\
\hline IN05 & $\mathrm{CZ}$ & 2005 & Bankruptcy \\
\hline \multicolumn{4}{|c|}{ IN05 $=0.13 \mathrm{x}_{1}+0.04 \mathrm{x}_{2}+3.97 \mathrm{x}_{3}+0.21 \mathrm{x}_{4}+0.09 \mathrm{x}_{5}$} \\
\hline CH-index & SVK & 1998 & Bankruptcy \\
\hline \multicolumn{4}{|c|}{$\mathrm{CH}=0.37 \mathrm{x}_{1}+0.25 \mathrm{x}_{2}+0.21 \mathrm{x}_{3}-0.1 \mathrm{x}_{4}-0.07 \mathrm{x}_{5}$} \\
\hline Zmijewski model & USA & 1984 & Logit and Probit \\
\hline \multicolumn{4}{|c|}{$\mathrm{ZM}=-4.336-4.413 \mathrm{x}_{1}+5.679 \mathrm{x}_{2}+0.004 \mathrm{x}_{3}$} \\
\hline Jakubík-Teplý model & $\mathrm{CZ}$ & 2006 & Logit and Probit \\
\hline \multicolumn{4}{|c|}{$\mathrm{JT}=2.4192+2.5779 \mathrm{x}_{1}+1.7863 \mathrm{x}_{2}-3.4902 \mathrm{x}_{3}-2.4172 \mathrm{x}_{4}+1.7679 \mathrm{x}_{5}-3.3062 \mathrm{x}_{6}-2.2491 \mathrm{x}_{7}$} \\
\hline Sharita model & Japan & 2003 & Logit and Probit \\
\hline
\end{tabular}

In the last step we divided companies into the two categories, namely: bankrupt companies and non-bankrupt companies. As a basic rule for including companies into the categories of bankrupt or non-bankrupt companies we used financial ratio of indebtedness of the company.

ttttttttt ttaaaaaattaa - ttttttttt

scttcccccettccaaccttaa

ttttttttt ccttcccccttccaaccttal

We calculated this financial ratio in every of 74 companies from Slovak Republic based on their financial statements for 2015. Our reasoning was following - if the result of this financial ratio was higher than 0 , then we classified the company to the non-bankrupt category. If the result of this financial ratio was lower than 0 then we classified the company to the bankrupt category. In this step we compared the results of selected prediction models with the results of selected financial ratio. Based on this comparison we tried to capture explanatory power and success of individual models in the Slovak conditions. Svabova, Durica (2016)

\section{Data analysis and Results}

In the third chapter we state the results of calculated prediction models, results of financial ratio of indebtedness and comparison between these results. As we mentioned in the previous chapter, first of all it was necessary to calculate 8 prediction models in every of 74 selected companies from Slovak Republic based on their financial statements for 2015. In the second step, we calculated financial ratio of indebtedness. We did this calculation in every of 74 selected companies from Slovak Republic based on their financial statements for 2015. These calculations were the base for our comparison and it was the aim of the third step of this chapter. 


\subsection{Results of Prediction models}

As we mentioned above, we chose 8 prediction models, namely: Springate model, Poznanski model, Fulmer model, IN05, CH-index, Zmijewski model, Jakubík-Teplý model, Sharita model. Our aim was to apply and calculate 8 prediction models in our sample of 74 companies from Slovak Republic based on data from their financial statements for 2015. We captured our results in this table number 2 . In this table we divided the results into the two categories, namely: bankrupt and non-bankrupt. It means that in this table we show the number of companies which belong to bankrupt categories (their bankrupt is very probably) and the number of companies which belong to non-bankrupt categories (their bankrupt is not very probably), according to particular model. The allocation of companies into the created categories was dependent on the conditions of the particular model.

Table 2. Allocation of companies into the categories according to selected models

\begin{tabular}{|c|c|c|}
\hline \multirow{2}{*}{ Model } & \multicolumn{2}{|c|}{ Category } \\
\hline & Bankrupt & Non-bankrupt \\
\hline Springate model & 31 & 43 \\
\hline Poznanski model & 12 & 62 \\
\hline Fulmer model & 1 & 73 \\
\hline IN05 & 60 & 14 \\
\hline CH-index & 73 & 1 \\
\hline Zmijewski model & 7 & 67 \\
\hline Jakubík-Teplý model & 59 & 15 \\
\hline Sharita model & 74 & 0 \\
\hline
\end{tabular}

In this table number 2 we can see that in Springate model the situation is almost in balanced. This model classified 31 companies into the bankrupt category and their bankruptcy is highly probable. The break point for this decision was 0.862 , it means that if the result of this model was higher than 0.862 than we included the company into the non-bankrupt category, vice versa. Poznanski model classified 12 companies into the bankrupt category and 62 companies into the non-bankrupt category. The break point for this decision was 0 . The third model which we calculated was Fulmer model and this model classified almost every of companies into the non-bankrupt category. The break point for this decision was 0. Another model was IN05 this model classified 60 companies into the bankrupt category and other companies classified into the non-bankrupt category. The break point was 1.6. CHindex classified almost every of companies into the bankrupt category, especially 73 companies. The break point was 2.5. Another model which we calculated was Zmijewski model and this model classified 7 companies into the bankrupt category and 67 companies into the non-bankrupt category. The break point for this decision was 0.5. Jakubík-Teplý model classified 59 companies into the bankrupt category and 15 companies into the nonbankrupt category. The break point for this decision was 0.5 . The last prediction model which we calculated was Sharita model and this model classified every of 74 companies into the bankrupt category.

\subsection{Results of indebtedness financial ratio}

As we mentioned in theoretical background we used this ratio for classification selected companies into the bankrupt and non-bankrupt category. Method of calculating of this indicator we stated in the second chapter. If the result of this ratio was higher than 0 , then we included the company into the non-bankrupt category and if the result of this ratio was lower than 0 , then we included the company into the bankrupt category. Kral, Kliestik (2015) Our results are following - this ratio included 66 companies into the non-bankrupt category where the 
bankrupt of company is unlikely and this ratio included 8 companies into the bankrupt category where the bankrupt of company is higher probably.

\subsection{Comparison of the results of prediction models with the results of indebtedness financial ratio}

In this last chapter we provide the comparison the results of prediction models with the results of indebtedness financial ratio. As we mentioned above, based on this comparison we tried to capture explanatory power and success of individual models in the Slovak conditions. Success of individual models we determined according to how many times the result of particular model was the same as the result of indebtedness financial ratio, the results of our comparison are captured in the following figure number 1 . This figure shows the results of prediction models and results of indebtedness financial ratio. This figure captures only the results in the area of non-bankrupt category. The reason was to do the best possible comparison.

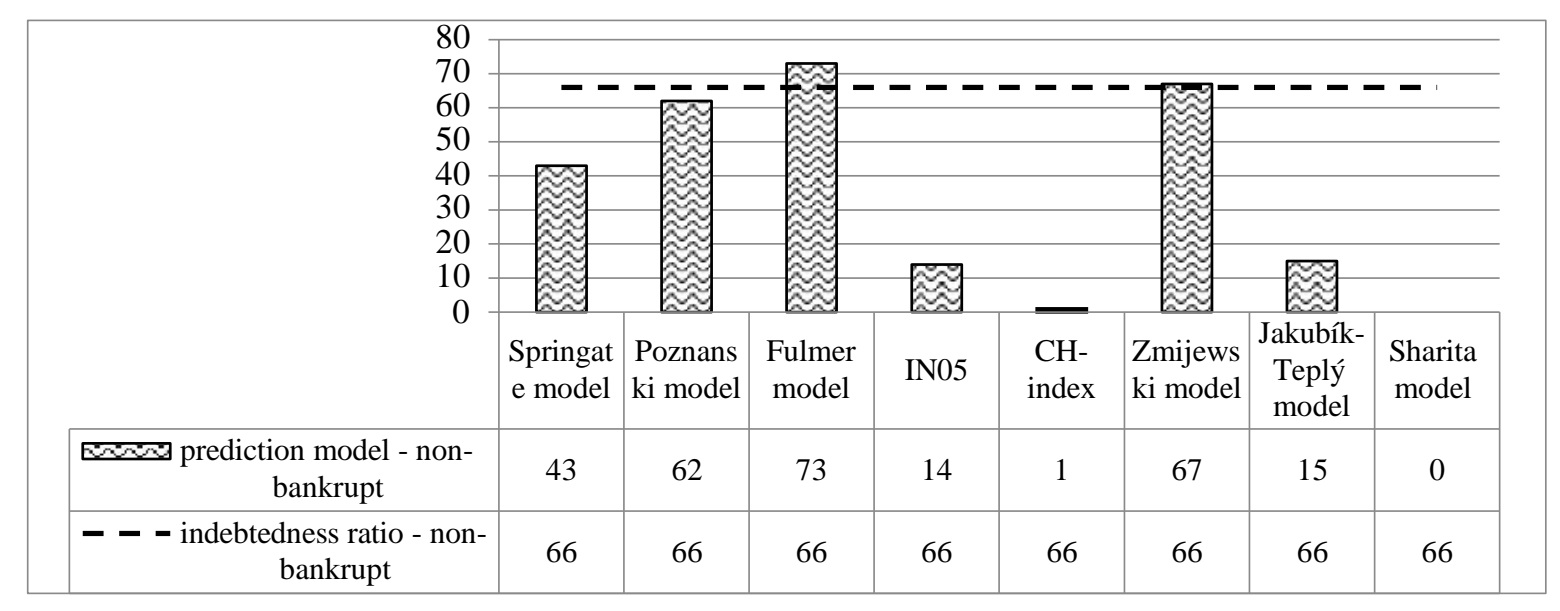

Figure 1. Comparison of the results of prediction models with the results of indebtedness financial ratio

In this figure we can see that the Fulmer model achieved the best results. It means that the indebtedness financial ratio placed 66 companies into the non-bankrupt zone and Fulmer model placed 73 companies into this category. The success of Fulmer model was more than $110 \%$. Good results also achieved Zmijewski model which placed 67 companies into the non-bankrupt zone, it means that their success was more than $101 \%$. Poznanski model also achieved good results because this model placed 62 companies into the non-bankrupt category and the success of this model was more than $93 \%$. On the fourth place was Springate model which success was more than $65 \%$ because this model placed 43 companies into the non-bankrupt category. Weak results achieved IN05, Jakubík-Teplý model and CH-index. But interesting is that these model were created in Czech Republic and even in Slovak Republic. Especially, $\mathrm{CH}$-index was created in Slovak Republic and this model placed only 1 company into the non-bankrupt category, it means that its success was only $1.5 \%$. But this model was primary created for agricultures companies. And it can be the reason why this model achieved very weak results even though it was created in Slovak Republic. The worst results achieved Sharita model and this model placed every of companies into the bankrupt zone and its success was $0 \%$.

\section{Conclusion}

The aim of this paper was capture explanatory ability and success of individual prediction models in Slovak conditions based on the comparison of the results of selected prediction models with the results of indebtedness financial ratio. For this purposes were used the sample of 74 companies from Slovak Republic. As an input data we used information from their financial statements for 2015. We can state that the best results were achieved by Fulmer, Poznanski and Zmijewski model. Weak results achieved IN05, CH-index and Sharita model. 


\section{Acknowledgements}

This research was financially supported by the Slovak Research and Development Agency - Grant NO. APVV14-0841: Comprehensive Prediction Model of the Financial Health of Slovak Companies.

\section{References}

Altman, E. I. (1968). Financial Ratios, Discriminant Analysis and the Prediction of Corporate Bankruptcy. Journal of Finance, 23 (4), 589-609.

Beaver, W. (1966). Financial ratios as predictors of failure. Journal of Accounting Research (Supplement), 4, 71-102.

Fulmer, J.G. Jr. et al. (1984). A Bankruptcy Classification Model for Small Firms. Journal of Commercial Bank Lending, $25-37$.

Kliestik, T., Majerova, J. (2015). Selected issues of selection of significant variables in the prediction models, In: 10th International Scientific Conference Financial management of Firms and Financial Institutions, Ostrava.

Kollar, B., Kramarova, K., Valaskova, K. (2015). The Financial Distress Analysis of the Stated-Own Company by Applying Chosen Default Prediction Models in Condition of Slovakia, In: 3rd International Conference on Economics and Social Science (ICESS 2015), Paris.

Kral, P., Kliestik, T. (2015). Estimation of the level of risk based on the selected theoretical probability distributions, In: 10th International Scientific Conference Financial management of Firms and Financial Institutions, Ostrava.

Sharita, C.Y. (1995). Read the Sign of Business Failure. Journal of Risk and Management, 23, 117-138.

Springate, G. L.V. et al. (1983). Predicting Business Failures. CGA Magazine, 24 -27.

Spuchlakova, E., Valaskova, K., Adamko, P. (2015). The Credit Risk and its Measurement, Hedging and Monitoring, Procedia Economics and finance, (pp. 675 - 681).

Svabova, L., Durica M. (2016). Korelačná analýza prediktorov použitých v bankrotných predikčných modeloch na Slovensku. Ekonomicko-manazerske spektrum, 10 (1), 2-11.

Zmijewski, M. E. (1984). Methodological issues related to the estimation of financial distress prediction models. Journal of Accounting Research, 22, 59-86. 